\title{
Ingestive behavior and nitrogenous compounds balance of heifers on pastures of Urochloa brizantha cv. Marandu deferred and fertilized with nitrogen
}

\section{Comportamento ingestivo e balanço dos compostos nitrogenados de novilhas em pastos de Urochloa brizantha cv. Marandu diferidos e adubados com nitrogênio}

\author{
Poliana Batista de Aguilar ${ }^{1 *}$; Fábio Andrade Teixeira²; Fabiano Ferreira da Silva ${ }^{2}$; \\ Aureliano José Vieira Pires²; Paulo Valter Nunes Nascimento²; \\ Antônio Carlos Ribeiro Lima II ${ }^{3}$; Igor Alexandre de Souza ${ }^{3}$; \\ Otanael Oliveira dos Santos ${ }^{1}$; Rita Kelly Couto Brandão ${ }^{3}$; Alex Resende Schio ${ }^{1}$
}

\begin{abstract}
The objective of this study was to evaluate the effect of different levels of nitrogen on deferred pastures of Urochloa brizantha cv. Marandu, and their implications on ingestive behavior and nitrogenous compounds balance of Nellore heifers. This was a completely randomized design, with four treatments (nitrogen of levels) and four replications (number of fertilized paddocks). They were used 16 Nelore heifers, averaging eight months of age and initial body weight of $178.69 \pm 26.67 \mathrm{~kg}$ were distributed in four treatments of four animals each. Data were evaluated by analysis of variance and regression at 5\% probability. Behavioral activity showed no significant change $(\mathrm{P}>0.05)$ with the use of different nitrogen levels with average time of 576.25 minutes (10h:00min) spent on grazing, 509.84 minutes ( $8 \mathrm{~h}: 50 \mathrm{~min})$ on rumination, 315.16 minutes (5h:25min) in idling and 39 minutes in the feeding trough. For nitrogen intake, nitrogen digested and retained nitrogen ( $\mathrm{g} /$ day) and the nitrogen digested ( $\% \mathrm{~N}$ intake), there was an increasing linear effect $(\mathrm{P}<0.05)$ as a function of nitrogen levels. For nitrogen ureic in urine, there was an increasing linear effect $(\mathrm{P}<0.05)$ with an increase of $0.335 \mathrm{mg} / \mathrm{dL}$ for every $1 \mathrm{~kg} \mathrm{~N}$ applied. For nitrogen ureic in plasma, no effect $(\mathrm{P}>0.05)$ of nitrogen levels was found, averaging $15.79 \mathrm{mg} / \mathrm{dL}$. Behavioral activities of heifers were not affected by nitrogen levels in deferred pastures of Urochloa brizantha $\mathrm{cv}$. Marandu. The nitrogen intake, nitrogen retained (g/day), nitrogen digested (g/day) and ( $\% \mathrm{~N}$ intake), the concentration of nitrogen ureic in urine, and the excretion of urea and of nitrogen ureic in urine are affected by the increasing level of crude protein in the forage originated from nitrogen fertilization, under the studied conditions.
\end{abstract}

Key words: Deferment. Grazing time. Nitrogen fertilization. Urea. Urine.

\section{Resumo}

Objetivou-se com este estudo avaliar o efeito de diferentes doses de nitrogênio em pastos de Urochloa brizantha cv. Marandu diferidos, e suas implicações sobre o comportamento ingestivo e o balanço de compostos nitrogenados de novilhas Nelore. Utilizou-se o delineamento inteiramente ao acaso, com

\footnotetext{
${ }^{1}$ Drs. em Zootecnia, Departamento de Zootecnia, Universidade Estadual do Sudoeste da Bahia, UESB, Itapetinga, BA, Brasil. E-mail: poliana.aguilar@bol.com.br; otanael.santos@bol.com.br; resendezoo@hotmail.com

2 Profs. Drs., Departamento de Zootecnia, UESB, Itapetinga, BA, Brasil. E-mail: fteixeira@uesb.edu.br; ffsilvauesb@hotmail. com; aurelianojvp@yahoo.com.br; pvalter@uesb.edu.br

${ }^{3}$ Discentes do Curso de Doutorado em Zootecnia, Departamento de Zootecnia, UESB, Itapetinga, BA, Brasil. E-mail: antoniozootecnista@yahoo.com.br; igordadim@hotmail.com; kelly_brandao@hotmail.com

* Author for correspondence
} 
quatro tratamentos (doses de nitrogênio) e quatro repetições (número de piquetes adubados). Foram utilizadas 16 novilhas da raça Nelore, com média de oito meses de idade e com peso corporal inicial de 178,69 $\pm 26,67 \mathrm{~kg}$, sendo quatro novilhas por tratamentos. Os resultados foram avaliados por meio de análise de variância e regressão a 5\% de probabilidade. As atividades comportamentais dos animais não se alteraram $(\mathrm{P}>0,05)$ com o uso das diferentes doses de nitrogênio nos pastos com tempos médios de 576,25 minutos (10h:00min) em pastejo, 509,84 minutos (8h:50min) em ruminação, 315,16 minutos ( $5 \mathrm{~h}: 25 \mathrm{~min}$ ) em ócio e 39 minutos alimentando no cocho. Para o nitrogênio ingerido, nitrogênio digerido e o nitrogênio retido ( $\mathrm{g} /$ dia) e o nitrogênio digerido ( $\%$ do $\mathrm{N}$ ingerido), houve efeito linear crescente $(\mathrm{P}<0,05)$ em função das doses de nitrogênio. Para o nitrogênio ureico na urina, houve efeito linear crescente $(\mathrm{P}<0,05)$ com incremento de $0,335 \mathrm{mg} / \mathrm{dL}$ para cada $1 \mathrm{~kg}$ de $\mathrm{N}$ aplicado. Para o nitrogênio ureico no plasma não houve efeito $(\mathrm{P}>0,05)$ das doses de nitrogênio, com média de $15,79 \mathrm{mg} / \mathrm{dL}$. As atividades comportamentais das novilhas não são afetadas pelas doses de nitrogênio em pastos de Urochloa brizantha $\mathrm{cv}$. Marandu diferidos. O nitrogênio ingerido, nitrogênio retido (g/dia), o nitrogênio digerido ( $\mathrm{g} /$ dia) e (\% do $\mathrm{N}$ ingerido), a concentração de nitrogênio ureico na urina, e as excreções de ureia e de nitrogênio ureico na urina são influenciados pela quantidade crescente de proteína bruta na forragem oriundas da adução nitrogenada, nas condições de realização desta pesquisa.

Palavras-chave: Adubação nitrogenada. Diferimento. Tempo de pastejo. Ureia. Urina.

\section{Introduction}

Among the alternatives to balance the seasonality of forage production, deferment has shown promise for being inexpensive and easily adopted (EUCLIDES et al., 2007). Deferment of grazing is a management strategy that consists in selecting a particular area of the property and fencing off from grazing, usually in late summer, in order to ensure forage accumulation to be used for grazing during forage shortage period (SANTOS, 2009b).

Forage species most indicated for this practice have low accumulation of stems and good retention of green leaves, resulting in minor reductions in nutritional value over time, in this case, the genus Brachiaria (Urochloa) stands out (EUCLIDES et al., 2007), especially Urochloa brizantha cv. Marandu. Nitrogen fertilization can allow greater flexibility in the pasture deferment period, since the nitrogen increases the growth rate of the grass and thus the amount of forage produced per unit time (SANTOS et al., 2009a). Nitrogen also has an important influence on nutritional value of forages, and consequently on the stocking rate and gain per hectare, maximizing animal performance (VITOR et al., 2009).

The grazing cattle farming is characterized by a number of factors and their interactions can affect the ingestive behavior of the animals, interfering with their performance and hence the viability of the property (PARDO et al., 2003). According to Palhano et al. (2007), the daily forage consumption is essential for a greater understanding of the behavior of grazing animals, directly influenced by factors related to forage plant and animal. Under grazing, the dry matter consumption is primarily affected by the availability of forage, accompanied by the vegetation structure (density, height, leaf:stem ratio) (MORAES et al., 2005). Animals tend to be more selective, grazing a pasture with a lower leaf: stem ratio and a lower availability of forage (ZANINE et al., 2006).

Creatinine is a nitrogenous compound produced from muscle phosphocreatine. The amount of creatinine formed per day depends on the amount of creatine in the body, which, in turn, depends on muscle mass (KANEKO et al., 1997). The concentration of creatinine in urine as indicator of urinary production can be used to estimate the excretion of purine derivatives and other nitrogenous compounds (CHEN et al., 1995).

According to Berchielli et al. (2011), the procedures for determining the nitrogen intake and nitrogen lost (feces and urine) can generate estimation errors in nitrogen balance. Under protein deficiency, there may be intracellular reduction in free amino acid content, both essential and nonessential, and decreased urinary excretion of nitrogen, resulting in 
less loss of organic protein. The balance of nitrogen compounds can reflect in the productive response by means of the final products absorbed and level of excreted losses, besides being positively correlated with the urea concentration found in urine, nitrogen plasma levels and nitrogen intake of animals (VAN SOEST, 1994).

The present study aimed to evaluate the effect of different levels of nitrogen on deferred pastures of Urochloa brizantha cv. Marandu, and their implications on ingestive behavior and nitrogenous compounds balance of Nellore heifers.

\section{Material and Methods}

The experiment was conducted at the Farm Boa Vista, municipality of Macarani, State of Bahia, Central-Southern Bahia, located at 15³3'46” South latitude and $40^{\circ} 25^{\prime} 38^{\prime \prime}$ 'West longitude, at an altitude of $315 \mathrm{~m}$, from March 18 to November 07, 2013. The climate in the region is tropical (Aw), with a dry season, according to the Köppen classification. Climate data of temperature and rainfall were collected using a thermometer and rain gauge placed in the experimental area (Table 1).

Table 1. Monthly mean values of maximum, minimum and average temperature $\left({ }^{\circ} \mathrm{C}\right)$ and rainfall $(\mathrm{mm})$ during the study period.

\begin{tabular}{|c|c|c|c|c|c|c|c|c|c|}
\hline & Mar & Apr & May & Jun & Jul & Aug & Sep & Oct & Nov \\
\hline & \multicolumn{4}{|c|}{ Deferment period } & \multicolumn{5}{|c|}{ Utilization period } \\
\hline Maximum temperature & 30.1 & 26.2 & 25.6 & 24.0 & 26.8 & 30.0 & 29.6 & 32.4 & 30.8 \\
\hline Minimum temperature & 16.7 & 16.2 & 15.2 & 14.5 & 16.5 & 17.6 & 17.9 & 18.9 & 20.2 \\
\hline Average temperature & 23.4 & 21.2 & 20.4 & 19.3 & 21.7 & 23.8 & 23.7 & 25.6 & 25.5 \\
\hline Rainfall index & 19.0 & 67.6 & 28.0 & 33.0 & 25.0 & 30.0 & 64.0 & 22.0 & 30.0 \\
\hline
\end{tabular}

Source: Elaboration of the authors.

The experimental area was 10 hectares (ha) consisting of Urochloa brizantha cv. Marandu, planted about 10 years ago, divided into 16 paddocks with approximately 0.6 ha each, the nitrogen levels were randomly selected according to the treatments.

It was used a completely randomized design (CRD) with four treatments (of nitrogen) and four repetitions (number of fertilized paddocks), as follows: $\mathrm{T} 1=$ differed pasture without nitrogen fertilization; $\mathrm{T} 2=$ deferred pasture with $50 \mathrm{~kg}$ de N.ha-1 ${ }^{-1}$ T3 = deferred pasture with $100 \mathrm{~kg}$ de N.ha-1; and $\mathrm{T} 4=$ deferred pasture with $150 \mathrm{~kg}$ de N.ha-1 .

The soil of the experimental area was Podzolic Red Yellow Eutrophic Equivalent (EMBRAPA, 1999). Soil samples were collected before nitrogen fertilization and chemical analysis showed the following characteristics in the layer 0-20 cm (Table 2).

Table 2. Chemical analysis of the experimental area.

\begin{tabular}{|c|c|c|c|c|c|c|c|c|c|c|c|c|c|}
\hline \multicolumn{5}{|c|}{$\mathrm{pH} \mathbf{m g} / \mathrm{dm}^{3}$} & \multicolumn{5}{|c|}{$\mathrm{cmol} / \mathrm{dm}^{3}$ soil } & \multicolumn{3}{|c|}{$\%$} & \multirow{2}{*}{$\begin{array}{l}\text { mg/dm } \\
\text { O.M. }\end{array}$} \\
\hline Level & $\left(\mathrm{H}_{2} \mathrm{O}\right)$ & $\mathrm{P}$ & $\mathrm{K}^{+}$ & $\mathrm{Ca}^{2+}$ & $\mathrm{Mg}^{2+}$ & $\mathrm{Al}^{3+}$ & $\mathrm{H}^{+}$ & S.B. & $\mathrm{t}$ & $\mathrm{T}$ & $\mathrm{V}$ & $\mathrm{m}$ & \\
\hline 0 & 5.7 & 1.0 & 0.3 & 1.6 & 1.3 & 0.3 & 2.4 & 3.2 & 3.4 & 5.8 & 54.3 & 7.5 & 3.58 \\
\hline $50 \mathrm{~N}$ & 5.8 & 1.0 & 0.4 & 1.7 & 1.3 & 0.3 & 2.6 & 3.4 & 3.7 & 6.2 & 54.3 & 7.8 & 3.91 \\
\hline $100 \mathrm{~N}$ & 5.8 & 1.0 & 0.5 & 1.5 & 1.3 & 0.2 & 2.2 & 3.3 & 3.5 & 5.7 & 57.0 & 6.8 & 3.75 \\
\hline $150 \mathrm{~N}$ & 5.6 & 1.0 & 0.3 & 1.4 & 1.2 & 0.2 & 2.6 & 3.0 & 3.2 & 5.8 & 51.0 & 7.3 & 4.12 \\
\hline
\end{tabular}

Source: Elaboration of the authors. 
The experiment lasted 230 days, including 107 days of deferment, 15 days of adaptation of animals to the experimental diet and 108 days of grazing and collection of data. From March 18 to April 3, 2013, regulator animals were placed in the experimental area to perform the standardization grazing to a residual height between $15-20 \mathrm{~cm}$. Then, the division of paddocks was made with fences of two oval electrified wire strands and placed collective plastic drinkers and troughs at a distance of approximately $5 \mathrm{~m}$ from each other, with one drinker for each paddock, and the number of troughs according to the number of animals.

Paddocks were closed at the entrance of the animals for 107 days and used from July 21 to November 7, 2013, a dry period, suitable for the start of use of deferred pastures in the region in an attempt to adjust a leaf blade supply to $3.6 \%$ body weight, considering the amount of accumulated leaf blade during the deferment period.

Regarding the values of base saturation of the soil (Table 2), there was no need for correction of acidity or potassium application, since the results were considered good (RIBEIRO et al., 1999). Despite the low content of phosphorus (CANTARUTTI et al., 1999), there was no phosphate fertilization, as the practice of deferment is typically used in lowtech systems.

The source of nitrogen $(\mathrm{N})$ applied was urea $(45 \% \mathrm{~N})$, which was applied by throw, according to the treatments $\left(111 ; 222\right.$ and $\left.333 \mathrm{~kg} \cdot \mathrm{ha}^{-1}\right)$ related to the levels of 50, 100 and $150 \mathrm{~kg} \mathrm{~N} \cdot \mathrm{ha}^{-1}$, respectively. The doses were divided in two applications, the first on April 17, 2013, and the second on June 6, 2013, both during rainy seasons.

Forage evaluations were made every 27 days, being characterized the beginning of grazing, the values of the $1^{\text {st }}$ forage collection ( 0 days of grazing) and $2^{\text {nd }}$ forage collection (27 days of grazing); and the final period of grazing, the values of the $3^{\text {rd }}$ forage collection (54 days of grazing) and $4^{\text {th }}$ forage collection (81 days of grazing).

In order to estimate forage production, 5 samples were randomly taken from each paddock, $5 \mathrm{~cm}$ from the ground, using pruning shears and a square of $0.70 \times 0.70 \mathrm{~m}$, totaling $0.49 \mathrm{~m}^{2}$ area. All samples were weighed, homogenized and divided into two representative sub-samples: one was separated into leaf blade, stem (stem + pseudostem) and dead material, , considering that the proportion of each morphological component was expressed as a percentage of total weight, being packed in labeled paper bags and dried in a forced ventilation oven at $60^{\circ} \mathrm{C}$ for 72 hours. The division of the dry weight of leaf blade by the dry weight of stem resulted in leaf:stem ratio. The crude protein of the simulated grazing was determined following methodologies described by Silva and Queiroz (2002). Values of availability of structural and nutritional components and leaf:stem ratio are shown in Table 3.

Heifers were given a previously balanced supplement to $0.2 \%$ body weight, for all treatments, with the goal of achieving an average daily gain of $0.400 \mathrm{~kg}$ (NRC, 1996). The supplementation was provided daily at 10 a.m., in plastic, collective and uncovered troughs to minimize the interference of substitutive effect of supplement intake on forage intake behavior (ADAMS, 1985). The supplement was composed of ground corn grain (58.3\%); soybean meal (25.4\%); mineral salt (8.3\%) and 9: 1 urea + ammonium sulfate $(8 \%)$, with the following chemical composition: dry matter $(79.9 \%)$; crude protein $(32.9 \%)$; neutral detergent fiber corrected for ash and protein $(28.0 \%)$; acid detergent fiber (8.9\%); lignin (0.5\%); ether extract (2.8\%); mineral matter $(9.2 \%)$ and non-fiber carbohydrate $(50 \%)$, in the percentage of dry matter. 
Table 3. Availability of structural and nutritional components, in $\mathrm{kg} \mathrm{DM} \cdot \mathrm{ha}^{-1}$, and leaf:stem ratio (L:S), of deferred pastures of Urochloa brizantha cv. Marandu fertilized with nitrogen.

\begin{tabular}{cccccc}
\hline & & \multicolumn{4}{c}{ Nitrogen level (kg.ha $\left.\mathbf{H}^{-1}\right)$} \\
\cline { 3 - 5 } & Grazing & $\mathbf{0}$ & $\mathbf{5 0}$ & $\mathbf{1 0 0}$ & $\mathbf{1 5 0}$ \\
\hline \multirow{2}{*}{ ADMLB } & Initial & 1006 & 1337 & 1668 & 1924 \\
& Final & 485 & 703 & 688 & 567 \\
\hline \multirow{2}{*}{ ADMS } & Initial & 873 & 1307 & 1765 & 1882 \\
& Final & 539 & 1026 & 771 & 803 \\
\hline \multirow{2}{*}{ APDDM } & Initial & 2877 & 3132 & 3364 & 4853 \\
& Final & 2680 & 2530 & 2448 & 2719 \\
\hline Crude protein & Initial & 4.56 & 5.52 & 6.47 & 6.65 \\
& Final & 7.27 & 6.68 & 7.97 & 9.05 \\
\hline \multirow{2}{*}{ NDFap } & Initial & 70.23 & 68.57 & 66.90 & 67.86 \\
& Final & 67.04 & 69.06 & 66.82 & 67.21 \\
\hline L:S ratio & Initial & 1.56 & 1.44 & 1.57 & 1.38 \\
& Final & 0.87 & 0.75 & 0.75 & 0.83 \\
\hline
\end{tabular}

ADMLB = availability of dry matter of leaf blade; ADMS = availability of dry matter of stem; DMSpd = availability of potentially digestible dry matter; $\mathrm{CP}=$ crude protein; NDFap = neutral detergent fiber corrected for ash and protein.

Source: Elaboration of the authors.

To estimate the voluntary consumption of forage, we used the internal marker indigestible NDF (NDFi) (MERTENS, 2002). The apparent digestibility (AD) of nutrients was determined by the methodology described by Silva and Leão (1979). The consumption and digestibility of dry matter and nutrients are listed in Table 4.

Table 4. Consumption, in kg.day ${ }^{-1}$, and digestibility, in percentage, of dry matter and nutrients of Nellore heifers on deferred pastures of Urochloa brizantha cv. Marandu fertilized with nitrogen.

\begin{tabular}{|c|c|c|c|c|}
\hline \multirow{3}{*}{ Intake and digestibility } & \multicolumn{4}{|c|}{ Nitrogen level $\left(\mathrm{kg}^{2} \mathrm{ha}^{-1}\right)$} \\
\hline & $\mathbf{0}$ & 50 & 100 & 150 \\
\hline & \multicolumn{3}{|c|}{ Kg.day $^{-1}$} & \\
\hline Consumption of DMT & 3.11 & 3.70 & 3.71 & 3.88 \\
\hline Consumption of NDFapT & 2.00 & 2.39 & 2.34 & 2.47 \\
\hline Consumption of CP & 0.30 & 0.35 & 0.39 & 0.43 \\
\hline Consumption of NFC & 0.62 & 0.74 & 0.77 & 0.75 \\
\hline Consumption of TDN & 1.82 & 2.18 & 2.34 & 2.45 \\
\hline Digestibility of CP (\%) & 55.37 & 54.40 & 63.43 & 64.41 \\
\hline Digestibility of NFC (\%) & 82.00 & 87.03 & 91.22 & 91.21 \\
\hline TDN (\%) & 58.33 & 58.72 & 63.29 & 62.60 \\
\hline
\end{tabular}

$\mathrm{DMT}=$ dry matter total $($ pasture + supplement); NDFapT $=$ neutral detergent fiber corrected for ash and protein total (pasture + supplement); $\mathrm{CP}=$ crude protein; $\mathrm{NFC}=$ non fiber carbohydrates; TDN $=$ total digestible nutrients.

Source: Elaboration of the authors.

For the evaluation of ingestive behavior, 16 animals, four per treatment, were numerically identified visibly with colored ribbons in the neck, and variables were evaluated visually by a trained observer. The studied behavioral data were: time on grazing, rumination, idle and trough; and observations were carried out with the aid of digital stopwatches and binoculars. Behavioral activities were considered mutually exclusive, as defined by Pardo et al. (2003). For recording the time spent on 
each activity, the animals were observed visually, every 5 minutes (MEZZALIRA et al., 2011) for 24 hours every 27 days. The average number of ruminating chews per ruminal bolus (CRB), the time spent ruminating each bolus (TRB) and the number of bolus ruminated (NBR) in the period was obtained by registering with digital stopwatches nine values per animal, according to the method described by Bürger et al. (2000). The total chewing time (TCT) was determined by the sum of grazing time and rumination time.

The discretization of the time series was performed directly in the data collection spreadsheets, with a count of discrete periods of grazing, rumination, idle and trough, as described by Silva et al. (2006). The average duration of each discrete period was obtained by dividing the daily times for each activity by the number of discrete periods.

Feeding efficiency was calculated according to Bürger et al. (2000), in which the efficiency of consumption of pasture dry matter = consumption of pasture dry matter, in $\mathrm{kg} /$ feeding time, in hours; the efficiency of consumption of neutral detergent fiber corrected for ash and protein = consumption of neutral detergent corrected for ash and protein, in $\mathrm{kg} /$ feeding time, in hours; the efficiency of consumption of total digestible nutrients of the diet $=$ consumption of total digestible nutrients of the diet, in $\mathrm{kg} /$ feeding time, in hours; the efficiency of rumination of pasture dry matter $=$ consumption of pasture dry matter, in $\mathrm{kg} /$ rumination time, in hours; the efficiency of rumination of neutral detergent fiber corrected for ash and protein of the pasture = consumption of neutral detergent fiber corrected for ash and protein of the pasture, in $\mathrm{kg} /$ rumination time, in hours.

To estimate the balance of nitrogen compounds, spot urine samples were collected in spontaneous urination from four animals per treatment, totaling 16 animals, every 27 days, about 4 hours after delivery of the supplement, as described by Barbosa
(2006). Samples were filtered through gauze and a $10 \mathrm{~mL}$ aliquot was separated and diluted with $40 \mathrm{~mL}$ sulfuric acid $(0.036 \mathrm{~N})$ according to the methodology of Valadares et al. (1999) intended for quantification of urinary concentrations of urea, nitrogen and creatinine.

Blood samples were taken by jugular vein puncture, also from four animals of each treatment, totaling 16 animals, every 27 days, about 4 hours after providing the supplement, using $5 \mathrm{~mL}$ tubes (Vacutainer $^{T M}$ ) with EDTA. Then, the blood samples were centrifuged at 2,400 rpm for 15 minutes, and the plasma placed in $5 \mathrm{~mL}$ microtubes and frozen at $-20^{\circ} \mathrm{C}$ until analysis.

Creatinine concentrations in urine and urea concentrations in urine and plasma were estimated using commercial kits (Bioclin). The conversion of urea into nitrogen ureic was made by multiplying the values by a factor of 0.4667 .

Nitrogen balance ( $\mathrm{N}$ retained, g/day) was calculated using the following formula:

$$
\begin{gathered}
\mathrm{N} \text { retained }(\mathrm{g})=\{\mathrm{N} \text { intake }(\mathrm{g})-\mathrm{N} \text { fecal }(\mathrm{g})-\mathrm{N} \\
\text { urine }(\mathrm{g})\}
\end{gathered}
$$

Where: $\mathrm{N}$ retained $=$ nitrogen retained in the animal organism; $\mathrm{N}$ intake $=$ nitrogen intake by the animal; $\mathrm{N}$ fecal $=$ nitrogen excreted in the feces; $\mathrm{N}$ urine $=$ nitrogen excreted in the urine.

Creatinine excretion (mg/day) used to estimate the urine volume through spot samples was obtained for each animal according to the equation described by Chizzotti (2004):

$$
\mathrm{CE}=\{32,27-0,01093 \times \mathrm{BW}\}
$$

Where: $\mathrm{CE}=$ daily creatinine excretion (mg/day); $\mathrm{BW}=$ body weight $(\mathrm{kg})$.

Urine volume was estimated from the relationship between creatinine excretion ( $\mathrm{mg} /$ day) obtained in the previous equation, and the average concentration in urine samples $(\mathrm{mg} / \mathrm{dL})$.

Analyses of variance were run at a significance level of $5 \%$, regression models of variables studied 
were tested according to the levels of nitrogen applied tested, considering the determination coefficients. These analyses were performed using the Statistical and Genetic Analysis System SAEG (RIBEIRO JÚNIOR, 2001).

\section{Results and Discussion}

Behavioral activity of animals showed no significant change $(\mathrm{P}>0.05)$ with the use of different nitrogen levels in pastures, with average time of
576.25 minutes (10h:00min) spent on grazing, 509.84 minutes (8h:50min) on rumination, 315.16 minutes (5h:25min) in idling and 39 minutes in the feeding trough (Table 5). These results can be explained by the similarities in the leaf: stem ratio (Table 3) and dry matter consumption (Table 4), which affect negatively or positively the behavioral activity of animals, but, in this study, the treatments were similar. In addition, the supply of leaf blade was adjusted, thus providing similar grazing conditions for animals of all treatments.

Table 5. Behavioral activities, in minutes, of Nellore heifers on deferred pastures of Urochloa brizantha cv. Marandu fertilized with nitrogen.

\begin{tabular}{lccccccc}
\hline \multirow{2}{*}{\multicolumn{1}{c}{ Activity }} & $\mathbf{0}$ & $\mathbf{5 0}$ & $\mathbf{1 0 0}$ & $\mathbf{1 5 0}$ & $\mathbf{C V}^{\mathbf{1}}$ & $\mathbf{P}^{\mathbf{2}}$ & RE $^{\mathbf{3}}$ \\
\cline { 2 - 5 } & 608.75 & 596.88 & 545.63 & 553.75 & 14.4 & 0.352 & $\hat{\mathrm{Y}}=576.25$ \\
Grazing (min.) & 476.25 & 520.63 & 535.00 & 507.50 & 27.8 & 0.860 & $\hat{\mathrm{Y}}=509.84$ \\
Rumination (min.) & 303.13 & 284.38 & 331.88 & 341.25 & 39.6 & 0.788 & $\hat{\mathrm{Y}}=315.16$ \\
Idling (min.) & 51.88 & 38.75 & 28.13 & 38.13 & 38.6 & 0.335 & $\hat{\mathrm{Y}}=39.22$ \\
Trough (min.) & &
\end{tabular}

${ }^{1}$ Coefficient of variation, in percentage. ${ }^{2}$ Error probability. ${ }^{3}$ Regression equation.

Source: Elaboration of the authors.

According Sollenberger and Burns (2001), height, density, different parts of the plant, botanical composition of the canopy and the spatial arrangement are factors affecting the intake and digestion of forage plants, directly interfering with the ingestive behavior of herbivorous animals. The values found in this study are within the range of variation of behavioral activities cited by Euclides et al. (2000) and Brâncio (2003), who reported that, in general, grazing times range from 7 to 12 hours per day, and according to Fraser (1980) and Van Soest (1994), rumination times usually vary between 4 and 9 daily hours to animals on pasture.

Macêdo (2014) found no difference in the behavioral activity of Holstein/Zebu heifers on deferred pastures of Brachiaria decumbens cv. Basilisk, with average time of $9 \mathrm{~h}: 26 \mathrm{~min}$ on grazing, 7h:06min on rumination, $7 \mathrm{~h}: 02 \mathrm{~min}$ in idling and 24 minutes feeding in the trough. Zanine et al. (2007) worked with the ingestive behavior of Girolanda heifers, and verified an average time of 10h:56min on grazing, $7 \mathrm{~h}: 45 \mathrm{~min}$ on rumination, $6 \mathrm{~h}: 29 \mathrm{~min}$ in idling in pastures of Brachiaria brizantha cv. Marandu, results similar to those registered in this study.

There was no effect $(\mathrm{P}>0.05)$ of nitrogen levels on the number of periods and duration of behavioral activities with average values of $14.59 ; 11.50 ; 21.00$ and 5.41 for the number of periods; and 41.83; $48.80 ; 16.01$ and 7.39 for the duration of grazing, rumination, idling and trough, respectively, as shown in Table 6. The similarities for the number of periods and times on grazing, rumination, idling and in the trough were expected, since these variables were directly influenced by the behavioral activities in Table 5, possibly due to the same factors mentioned above. 
Table 6. Number of periods and duration time, in minutes, of behavioral activities of Nellore heifers on deferred pastures of Urochloa brizantha cv. Marandu fertilized with nitrogen.

\begin{tabular}{|c|c|c|c|c|c|c|c|}
\hline \multirow[b]{2}{*}{ Activity } & \multicolumn{4}{|c|}{ Nitrogen level (kg.ha-1) } & \multirow[b]{2}{*}{ CV\% ${ }^{1}$} & \multirow[b]{2}{*}{$\mathbf{P}^{2}$} & \multirow[b]{2}{*}{$\mathbf{R E}^{3}$} \\
\hline & $\mathbf{0}$ & 50 & 100 & 150 & & & \\
\hline Number of periods in grazing & 14.38 & 15.88 & 14.00 & 14.13 & 21.1 & 0.598 & $\hat{\mathrm{Y}}=14.59$ \\
\hline Number of periods in rumination & 11.75 & 10.88 & 10.38 & 13.00 & 23.9 & 0.261 & $\hat{\mathrm{Y}}=11.50$ \\
\hline Number of periods in idling & 20.13 & 21.75 & 19.63 & 22.50 & 20.3 & 0.504 & $\hat{\mathrm{Y}}=21.00$ \\
\hline Number of periods in the trough & 6.38 & 5.50 & 4.63 & 5.13 & 38.7 & 0.409 & $\hat{\mathrm{Y}}=5.41$ \\
\hline Grazing time per period ${ }^{4}$ & 44.49 & 38.55 & 41.18 & 40.70 & 26.5 & 0.751 & $\hat{\mathrm{Y}}=41.23$ \\
\hline Rumination time per period ${ }^{4}$ & 44.07 & 53.95 & 58.11 & 39.06 & 46.2 & 0.324 & $\hat{\mathrm{Y}}=48.80$ \\
\hline Idling time per period ${ }^{4}$ & 17.38 & 13.12 & 17.51 & 16.02 & 55.3 & 0.737 & $\hat{\mathrm{Y}}=16.01$ \\
\hline Time in the trough per period ${ }^{4}$ & 8.27 & 7.15 & 5.97 & 8.19 & 23.2 & 0.410 & $\hat{\mathrm{Y}}=7.39$ \\
\hline
\end{tabular}

${ }^{1}$ Coefficient of variation, in percentage. ${ }^{2}$ Error probability. ${ }^{3}$ Regression equation. ${ }^{4}$ Minutes.

Source: Elaboration of the authors.

Nitrogen levels did not influence $(\mathrm{P}>0.05)$ the total chewing time (TCT), number of bolus ruminated per day (NBR), number of chews per day $(\mathrm{NCd})$ and number of chews per bolus $(\mathrm{NCb})$ with mean values of $18.10 ; 766 ; 31.417$ and 42 , respectively (Table 7). Probably, the similarities of neutral detergent fiber corrected for ash and protein (NDFap) (Table 3), the consumption of dry matter, neutral detergent fiber corrected for ash and protein (NDFap), and non fiber carbohydrates (NFC) (Table 4) have contributed to this result.

Table 7. Ruminating chews of Nellore heifers on deferred pastures of Urochloa brizantha cv. Marandu fertilized with nitrogen.

\begin{tabular}{lcccccccc}
\hline & \multicolumn{9}{c}{ Nitrogen level (kg.ha-1 $^{-1}$ Activity } & $\mathbf{0}$ & $\mathbf{5 0}$ & $\mathbf{1 0 0}$ & $\mathbf{1 5 0}$ & $\mathbf{C V \%}^{\mathbf{1}}$ & $\mathbf{P}^{\mathbf{2}}$ & $\mathbf{R E}^{\mathbf{3}}$ & $\mathbf{R}^{\mathbf{2 , 4}}$ \\
\cline { 2 - 7 } TCT (h/day) & 18.08 & 18.63 & 18.01 & 17.69 & 11.7 & 0.846 & $\hat{\mathrm{Y}}=18.10$ & - \\
NBR (n/day) & 667 & 773 & 766 & 858 & 34.1 & 0.552 & $\hat{\mathrm{Y}}=766$ & - \\
NCd (n/day) & 28.332 & 32.653 & 31.161 & 33.526 & 29.6 & 0.698 & $\hat{\mathrm{Y}}=31.417$ & - \\
NCb (n/bolus) & 44 & 43 & 42 & 40 & 12.3 & 0.487 & $\hat{\mathrm{Y}}=42$ & - \\
TRB (sec/bolus) & 43.79 & 40.88 & 42.38 & 36.98 & 11.7 & 0.048 & $\hat{\mathrm{Y}}=43.844-0.0379 \mathrm{x}$ & 0.69 \\
\hline
\end{tabular}

${ }^{1}$ Coefficient of variation, in percentage. ${ }^{2}$ Error probability. ${ }^{3}$ Regression equation. ${ }^{4}$ Coefficient of determination. TCT $=$ total chewing time; $\mathrm{NBR}=$ number of bolus ruminated per day; $\mathrm{NCd}=$ number of chews per day; $\mathrm{NCb}=$ number of chews per bolus; $\mathrm{TRB}=$ time spent per ruminated bolus.

Source: Elaboration of the authors.

For the time spent per ruminated bolus (TRB), there was a decreasing linear effect $(\mathrm{P}<0.05)$ (Table 7). There was a decrease of 0.0379 seconds/bolus ruminated for every $1 \mathrm{~kg} \mathrm{~N}$ applied. It is assumed that the increasing availability of potentially digestible dry matter (Table 3 ) influenced this result. Silva et al. (2010) investigated Nellore steers on Brachiaria brizantha cv. Marandu, and reported 38 seconds per ruminated bolus for the supplementation level of $0.3 \%$ body weight; the values found by these authors were similar to those obtained in this research.

The efficiencies of consumption of dry matter
(ECDM) and neutral detergent fiber corrected for ash and protein (ECNDap), and the efficiencies of rumination of dry matter (ERDM) and neutral detergent fiber corrected for ash and protein (ERNDFap) were not influenced $(\mathrm{P}>0.05)$ by nitrogen levels, with average values of 0.354 ; $0.241 ; 0.418$ and 0.285 , respectively (Table 8). These results can be explained by the similarity in the consumption of DM and NDFap (Table 4). According to Dulphy et al. (1980), diets with high NDF content provide low efficiency of rumination and chewing, due to the particle size, resulting in lower intake and animal performance. 
There was an increasing linear effect $(\mathrm{P}>0.05)$ of nitrogen levels on the efficiencies of consumption of crude protein (ECCP) and total digestible nutrients (ECTDN), with increase of 0.1441 and $0.651 \mathrm{~kg} \cdot \mathrm{h}^{-1}$, for ECPCP and ECTDN, respectively, for every 1 kg N applied (Table 8).

These results were probably associated with the increased consumption of CP and TDN, and the digestibility of CP (Table 4), caused by the positive effects of nitrogen fertilization, and as a result of these factors, ECCP and ECTDN followed the same upward linear trend. With increasing consumption of $\mathrm{CP}$ and TDN, this process contributes positively to animal performance.

The urine volume was not influenced $(\mathrm{P}>0.05)$ by nitrogen levels, with an average volume of $5.43 \mathrm{~L} /$ day (Table 9). According to Mateus (2013), the greater consumption of nitrogen can induce increased intake of water and excretion in the urine, which was not observed herein.

Table 8. Feeding efficiency, in $\mathrm{kg} \cdot \mathrm{h}^{-1}$, of Nellore heifers on deferred pastures of Urochloa brizantha cv. Marandu fertilized with nitrogen.

\begin{tabular}{lcccccccc}
\hline & \multicolumn{9}{c}{ Nitrogen level (kg.ha' } & & & & & \\
Efficiency & $\mathbf{0}$ & $\mathbf{5 0}$ & $\mathbf{1 0 0}$ & $\mathbf{1 5 0}$ & $\mathbf{C V \%}^{\mathbf{1}}$ & $\mathbf{P}^{\mathbf{2}}$ & $\mathbf{E R}^{\mathbf{3}}$ & $\mathbf{R}^{\mathbf{2 , 4}}$ \\
\hline ECDM & 0.279 & 0.345 & 0.387 & 0.404 & 26.7 & 0.060 & $\hat{\mathrm{Y}}=0.354$ & - \\
ECNDFap & 0.192 & 0.238 & 0.261 & 0.272 & 25.7 & 0.066 & $\hat{\mathrm{Y}}=0.241$ & - \\
ECPB & 0.033 & 0.038 & 0.049 & 0.054 & 27.33 & 0.001 & $\hat{\mathrm{Y}}=32.59+0.1471 \mathrm{x}$ & 0.98 \\
ECTDN & 0.191 & 0.228 & 0.277 & 0.284 & 27.2 & 0.031 & $\hat{\mathrm{Y}}=196.264+0.651 \mathrm{x}$ & 0.93 \\
ERDM & 0.386 & 0.407 & 0.412 & 0.468 & 36.7 & 0.741 & $\hat{\mathrm{Y}}=0.418$ & - \\
ERNDFap & 0.264 & 0.281 & 0.279 & 0.315 & 35.7 & 0.787 & $\hat{\mathrm{Y}}=0.285$ & - \\
\hline
\end{tabular}

${ }^{1}$ Coefficient of variation, in percentage. ${ }^{2}$ Error probability. ${ }^{3}$ Regression equation. ${ }^{4}$ Coefficient of determination. ECDM $=$ efficiency of consumption of pasture dry matter; ECNDFap = efficiency of consumption of neutral detergent fiber corrected for ash and protein; ECCP = efficiency of consumption of crude protein; ECTDN = efficiency of consumption of total digestible nutrients; $\mathrm{ERDM}=$ efficiency of rumination of pasture dry matter; ERNDFap= efficiency of rumination of neutral detergent fiber corrected for ash and protein.

Source: Elaboration of the authors.

Table 9. Urine volume and balance of nitrogen compounds of Nellore heifers on deferred pastures of Urochloa brizantha cv. Marandu fertilized with nitrogen.

\begin{tabular}{|c|c|c|c|c|c|c|c|}
\hline \multirow[b]{2}{*}{ Item } & \multicolumn{4}{|c|}{ Nitrogen level $\left({\left.\mathrm{kg} . h a^{-1}\right)}\right.$} & \multirow[b]{2}{*}{ CV\% ${ }^{1}$} & \multirow[b]{2}{*}{$\mathbf{P}^{2}$} & \multirow[b]{2}{*}{$\mathbf{E R}^{3} \mathbf{R}^{2,4}$} \\
\hline & $\mathbf{0}$ & 50 & 100 & 150 & & & \\
\hline Urine volume (L/day) & 4.79 & 6.10 & 5.24 & 5.60 & 21.8 & 0.060 & $\hat{Y}=5.43$ \\
\hline $\mathrm{N}$ intake (g/day) & 47.68 & 55.45 & 62.43 & 69.50 & 27.0 & 0.011 & $\hat{\mathrm{Y}}=47.901+0.145 \mathrm{x}$ \\
\hline $\mathrm{N}$ feces (g/day) & 20.64 & 24.94 & 22.47 & 23.86 & 24.0 & 0.265 & $\hat{\mathrm{Y}}=22.98$ \\
\hline $\mathrm{N}$ digested (g/day) & 27.04 & 30.50 & 39.96 & 45.64 & 35.9 & 0.003 & $\hat{\mathrm{Y}}=26.001+0.131 \mathrm{x}$ \\
\hline $\mathrm{N}$ digested (\% $\mathrm{N}$ intake) & 55.37 & 54.40 & 63.43 & 64.41 & 14.0 & 0.006 & $\hat{Y}=53.978+0.0723 x$ \\
\hline $\mathrm{N}$ urine (g/day) & 41.60 & 27.08 & 42.92 & 46.34 & 47.4 & 0.121 & $\hat{\mathrm{Y}}=39.48$ \\
\hline $\mathrm{N}$ retained (g/day) & 20.44 & 26.15 & 30.88 & 37.11 & 45.1 & 0.021 & $\hat{\mathrm{Y}}=20.434+0.109 \mathrm{x}$ \\
\hline $\mathrm{N}$ retained (\% $\mathrm{N}$ intake $)$ & 41.16 & 46.04 & 48.13 & 51.97 & 26.9 & 0.219 & $\hat{\mathrm{Y}}=46.83$ \\
\hline $\mathrm{N}$ retained (\% $\mathrm{N}$ digested $)$ & 73.92 & 83.88 & 74.43 & 80.16 & 19.1 & 0.310 & $\hat{\mathrm{Y}}=78.10$ \\
\hline \multicolumn{8}{|l|}{ Concentrations (mg/dL) } \\
\hline $\mathrm{N}$ ureic in urine & 52.62 & 44.38 & 79.18 & 94.03 & 52.3 & 0.010 & $\hat{\mathrm{Y}}=41.498+0.335 \mathrm{x}$ \\
\hline $\mathrm{N}$ ureic in plasma & 17.46 & 14.66 & 15.40 & 15.66 & 34.2 & 0.688 & $\hat{Y}=15.79$ \\
\hline \multicolumn{8}{|l|}{ Excretions (g/day) } \\
\hline Urea in the urine & 5.48 & 5.84 & 9.19 & 10.63 & 47.8 & 0.009 & $\hat{\mathrm{Y}}=4.837+0.0384 \mathrm{x}$ \\
\hline $\mathrm{N}$ ureic in urine & 2.56 & 2.72 & 4.28 & 4.95 & 47.8 & 0.009 & $\hat{\mathrm{Y}}=2.254+0.0179 \mathrm{x}$ \\
\hline
\end{tabular}

${ }^{1}$ Coefficient of variation, in percentage. ${ }^{2}$ Error probability. ${ }^{3}$ Regression equation. ${ }^{4}$ Coefficient of determination: $\mathrm{R}^{2}=$ $1.00 ; 0.97 ; 0.79 ; 1.00 ; 0.79 ; 0.92 ; 0.92$, respectively. $\mathrm{N}=$ nitrogen.

Source: Elaboration of the authors. 
For nitrogen intake, nitrogen digested and nitrogen retention (g/day) and nitrogen digested (\% $\mathrm{N}$ intake), there was an increasing linear effect $(\mathrm{P}<0.05)$ depending on nitrogen levels (Table 9). There was an increase of 0,$145 ; 0.131$ and $0.109 \mathrm{~g} /$ day nitrogen intake, nitrogen digested and nitrogen retention, respectively, and $0.0723 \%$ of nitrogen digested ( $\% \mathrm{~N}$ intake) for each $1 \mathrm{~kg} \mathrm{~N}$ applied. These results can be attributed to the increasing amount of crude protein in forage (Table 3), combined with an increased consumption and digestibility of this nutrient (Table 4).

Nitrogen retention was important at this stage, since the animals were growing, and this nutrient is essential for the formation of muscle tissues. Pereira (2012) found significant values for nitrogen retention, which can be explained by the fact that the animals are growing and therefore require high amounts of nitrogen for the formation of tissues, similarly to that observed in this study.

Ammonia absorbed by the digestive tract is converted into urea in the liver and excreted in the urine or transferred to the intestines and degraded by microorganisms. For certain diet, the amount of urea, which is recycled to the rumen by saliva or rumen wall, is directly related to the consumption of nitrogen and the degradability of dietary nitrogen (OBARA et al., 1991).

Mateus (2013) evaluated the nitrogen balance of Nelore heifers on pastures of Brachiaria brizantha cv. Marandu deferred for 90 days, and found greater values of $\mathrm{N}$ digested of 71.93 (g/day) and $\mathrm{N}$ retained of 18.83 (g/day) for crude protein level of $19 \% \mathrm{BW}$. In this study, the highest values for $\mathrm{N}$ digested and $\mathrm{N}$ retained were 45.64 and $37.11 \mathrm{~g} /$ day, respectively, for the level of $150 \mathrm{~kg} \mathrm{~N} . \mathrm{ha}^{-1}$.

Nitrogen levels did not affect $(\mathrm{P}>0.05)$ the content of nitrogen in the feces and nitrogen in the urine $(\mathrm{g} /$ day), nor the nitrogen retention ( $\% \mathrm{~N}$ intake) and nitrogen retention ( $\% \mathrm{~N}$ digested), whose average values were $22.98 \mathrm{~g} /$ day; $39.48 \mathrm{~g}$ /day; $46.83 \%$ and $78.10 \%$, respectively (Table 9). According to Wilkerson et al. (1993) and Hoffman et al. (2001), there is a linear relationship between nitrogen consumption and nitrogen excretion in the feces and urine, which was not verified in this study. Possibly, the use of nitrogen by rumen microorganisms had been satisfactory, and the recycling of urea by the liver seems to had been effective, which caused similar excretion of nitrogen in feces and urine among treatments.

For nitrogen ureic in urine, there was an increasing linear effect $(\mathrm{P}<0.05)$ with an increase of $0.335 \mathrm{mg} / \mathrm{dL}$ for every $1 \mathrm{~kg} \mathrm{~N}$ applied. For nitrogen ureic in plasma, there was no effect $(\mathrm{P}>0.05)$ of nitrogen levels, averaging $15.79 \mathrm{mg} / \mathrm{dL}$ (Table 9). The increase in nitrogen ureic in urine was probably influenced by the increased consumption and digestibility of crude protein (Table 4). Valadares et al. (1997b, 1999) demonstrated that the serum urea level in the urine is positively related to nitrogen intake. In this regard, serum urea level is related to the use of dietary crude protein and higher levels can characterize inefficient use of protein and higher energy losses (PESSOA et al., 2009).

The non differentiation of nitrogen ureic in plasma may be related to efficient use of crude protein, according to Broderick and Clayton (1997), the high concentration of plasma urea is related to inefficient use of dietary PB. Valadares et al. (1997a) reported that values from 14.0 to $16 \mathrm{mg}$ / $\mathrm{dL}$ of nitrogen ureic in plasma represent the range within which there is no loss of dietary protein. In this study, the average value of plasma nitrogen ureic was $15.79 \mathrm{mg} / \mathrm{dL}$, which indicate that there was no loss of dietary protein.

The nitrogen ureic concentration in plasma has been used to obtain information about ruminant protein nutrition, by means of metabolic response to certain diet. In this way, it is possible to avoid economic losses from the excess supply of dietary protein and possible production, reproductive and environmental losses (CARVALHO et al., 2011). 
There was an increasing linear effect $(\mathrm{P}<0.05)$ according to the levels of nitrogen for urea excretion in urea and of nitrogen ureic in urine (Table 9). For each $1 \mathrm{~kg} \mathrm{~N}$ applied, it was registered an increment of 0.0384 and $0.0179 \mathrm{~g} /$ day, respectively. In accordance with Van Soest (1994), nitrogen excretion in urine is greater when increase the concentration of crude protein in the diet and nitrogen intake by the animal. This is similar to those obtained herein, which was probably affected by the growing increase in content and production of crude protein (Table 3), resulting in higher consumption of PB (Table 4), which may have caused the linear increase in excretion of urea and nitrogen ureic.

\section{Conclusions}

Behavioral activities of heifers were not affected by nitrogen levels in deferred pastures of Urochloa brizantha cv. Marandu. The nitrogen intake, nitrogen retained (g/day), nitrogen digested ( $\mathrm{g} /$ day) and $(\% \mathrm{~N}$ intake), the concentration of nitrogen ureic in urine, and the excretion of urea and of nitrogen ureic in urine are affected by the increasing level of crude protein in the forage originated from nitrogen fertilization, under the studied conditions.

\section{Acknowledgements}

To Bahia State Foundation for Research Support.

\section{References}

ADAMS, D. C. Effect of time of supplementation on performance, forage intake and grazing behavior or yearling beef steers grazing Russian wild ryegrass in the fall. Journal of Animal Science, Champaign, v. 61, n. 5, p. 1037-1042, 1985.

BARBOSA, M. A. A. F.; NASCIMENTO JÚNIOR, D.; CECATO, U. Dinâmica da pastagem e desempenho de novilhos em pastagem de capim-tanzânia sob diferentes ofertas de forragem. Revista Brasileira de Zootecnia,Viçosa, v. 35, n. 4, p. 1594-1600, 2006.
BERCHIELLI, T. T.; PIRES, A. V.; OLIVEIRA, S. G. Nutrição de ruminantes. Jaboticabal: Funep, 2011. 616 p.

BRÂNCIO, P. A.; EUCLIDES, V. P. B.; NASCIMENTO JÚNIOR, D.; FONSECA, D. M. da; ALMEIDA, R. G.; MACEDO, M. C. M.; BARBOSA, R. A. Avaliação de três cultivares de Panicum maximum Jacq. sob pastejo: comportamento ingestivo de bovinos. Revista Brasileira de Zootecnia, Viçosa, v. 32, n. 5, p. 1045-1053, 2003.

BRODERICK, G. A.; CLAYTON, M. K. A statistical evaluation of animal and nutritional factors influencing concentrations of milk urea nitrogen. Journal of Dairy Science, Champaign, v. 80, n. 11, p. 2964-2971, 1997.

BÜRGER, P. J.; PEREIRA, J. C.; QUEIROS, A. C.; SILVA, J. F. C.; VALADARES FILHO, S. C.; CECON, P. R.; CASALI, A. D. P. Comportamento ingestivo em bezerros holandeses alimentados com dietas contendo diferentes níveis de concentrado. Revista Brasileira de Zootecnia, Viçosa, v. 29, n. 1, p. 236-242, 2000.

CANTARUTTI, R. B.; ALVARES, V. V. H.; RIBEIRO, A. C. Amostragem do solo. In: RIBEIRO, A. C.; GUIMARAES, P. T. G.; ALVAREZ, V. V. H. (Ed.). Recomendação para o uso de corretivos e fertilizantes em Minas Gerais: $5^{\circ}$ aproximação. Viçosa, MG: Comissão de Fertilidade do Solo do Estado de Minas Gerais, 1999. p. 13-20.

CARVALHO, G. G. P.; GARCIA, R.; PIRES, A. J. V.; DETMANN, E.; SILVA, R. R.; PEREIRA, M. L. A.; SANTOS, A. B.; PEREIRA, T. C. J. Metabolismo de nitrogênio em novilhas alimentadas com dietas contendo cana-de-açúcar tratada com óxido de cálcio. Revista Brasileira de Zootecnia, Viçosa, v. 40, n. 3, p. 622-629, 2011.

CHEN, X. B.; MEJIA, A. T.; ORSKOV, E. R. Evaluation of the use of the purine derivative: creatinine ratio in spot urine and plasma samples as an index of microbial protein supply in ruminants: studies in sheep. Journal of Agricultural Science, Toronto, v. 125, n. 1, p. 137-143, 1995.

CHIZZOTTI, M. L.; VALADARES FILHO, S. C.; VALADARES, R. F. D.; MARTINS, F. H.; MARCONDES, M. I.; FONSECA, M. A.; PORTO, M. O.; PINA, D. S.; LEAL, T. L.; SILVA, J. M.; ARAUJO, A. M. Excreção de creatinina em novilhos e novilhas. In: REUNIÃO ANUAL DA SOCIEDADE BRASILEIRA DE ZOOTECNIA, 41., 2004, Campo Grande. Anais... Campo Grande: Sociedade Brasileira de Zootecnia, 2004.

DULPHY, J. P.; REMOND, B.; THERIEZ, M. Ingestive behavior and related activities in ruminants. In: RUCKECUSH, Y.; THIVEND, P. (Ed.). Digestive physiology and metabolism in ruminants. Wesport: A. V. I. Publication Co, 1980. p. 103-122. 
EMPRESA BRASILEIRA DE PESQUISA AGROPECUÁRIA - EMBRAPA. Centro Nacional de Pesquisa de Solos. Sistema brasileiro de classificação de solos. Brasília: Embrapa Produção de Informação-SPI; Rio de Janeiro: Embrapa Solos, 1999. 412 p.

EUCLIDES, V. P. B.; CARDOSO, E. G.; MACEDO, M. C. M.; OLIVEIRA, M. P. Consumo voluntário de Brachiaria decumbens cv. Basilisk e Brachiaria brizantha cv. Marandu sob pastejo. Revista Brasileira de Zootecnia, Viçosa, v. 29, n. 6, p. 2200-2208, 2000.

EUCLIDES, V. P. B.; FLORES, R.; MEDEIROS, R. N.; OLIVEIRA, M. P. Diferimento de pastos de Brachiaria cultivares Basilisk e Marandu, na região do Cerrado. Pesquisa Agropecuária Brasileira, Brasília, v. 42, n. 2, p. 273-280, 2007.

FRASER, A. F. Comportamiento de los animales de la granja. Zaragoza: Acribia, 1980. 291 p.

HOFFMAN, P. C.; ESSER, N. M.; BAUMAN, L. M.; DENZINE, S. L.; ENGSTROM, M.; CHESTER-JONES, H. Short communication: effect of dietary protein on growth and nitrogen balance of Holstein heifers. Journal of Dairy Science, Champaign, v. 84, n. 4, p. 843-847, 2001.

KANEKO, J. J.; HARVEY, J. W.; BRUSS, M. L. (Ed.). Clinical biochemistry of domestic animals. $5^{\text {th }}$ ed. New York: Academic Press, 1997. 294 p.

MACÊDO, J. D. B. Periodos de diferimento para pastos de Brachiaria decumbens. 2014. Tese (Doutorado em Zootecnia) - Universidade Estadual do Sudoeste da Bahia, UESB, Itapetinga.

MATEUS, R. G. Niveis de proteína bruta em suplementos múltiplos para recria de novilhas Nelore. 2013. Tese (Doutorado em Zootecnia) - Universidade Estadual do Sudoeste da Bahia, UESB, Itapetinga.

MERTENS, D. R. Gravimetric determination of amylase treated neutral detergent fiber in feeds with refluxing in beakers or crucibles: Collaborative study. Journal of AOAC International, Rockville, v. 85, n. 6, p. 1212-1240, 2002.

MEZZALIRA, J. C.; CARVALHO, P. C. F.; FONSECA, L.; BREMM, C.; REFFATTI, M. V.; POLI, C. H. E. C.; TRINDADE, J. K. Aspectos metodológicos do comportamento ingestivo de bovinos em pastejo. Revista Brasileira de Zootecnia, Viçosa, v. 40, n. 5, p. 1114-1120, 2011.

MORAES, E. H. B. K.; PAULINO, M. F.; ZERVOUDAKIS, J. T.; VALADARES FILHO, S. C.; MORAES, K. A. K. Avaliação qualitativa da pastagem diferida de Brachiaria decumbens stapf., sob Pastejo, no período da seca, por intermédio de três métodos de amostragem. Revista Brasileira de Zootecnia, Viçosa, v. 34, n. 1, p. 30-35, 2005.

NATIONAL RESEARCH COUNCIL- NRC. Nutrient Requirements of beef cattle. $7^{\text {th }}$ ed. Washington, DC.: Nat. Acad. Press, 1996. 242 p.

OBARA, Y.; DELLOW, D. W.; NOLAN, J. V. The influence of energy-rich supplements on nitrogen kinetics in ruminants In: TSUDA, T.; SASAKI, Y; KAWASHIMA, R. (Ed.). Physiological aspects of digestion and metabolism in ruminants. Tokyo: Academic Press, 1991. p. 515-539.

PALHANO, A. L.; CARVALHO, P. C. F.; DITTRICH, J. R.; MORAES, A.; SILVA, S. C.; MONTEIRO, A. L. G. Características do processo de ingestão de forragem por novilhas holandesas em pastagens de capim-mombaça. Revista Brasileira de Zootecnia, Viçosa, v. 36, n. 4, p. 1014-1021, 2007.

PARDO, R. M. P.; FISCHER, V.; BALBINOTTI, M.; MORENO, C. B.; FERREIRA, E. X.; VINHAS, R. I.; MONKS, P. L. Comportamento ingestivo diurno de novilhos em pastejo a níveis crescentes de suplementação energética. Revista Brasileira de Zootecnia, Viçosa, v. 32, n. 6, p. 1408-1418, 2003.

PEREIRA, T. C. J. Substituição do milho pelo farelo de algaroba em dietas peletizadas para cordeiros. 2012. Dissertação (Mestrado em Zootecnia) - Universidade Estadual do Sudoeste da Bahia, UESB, Itapetinga.

PESSOA, R. A. S.; LEÃO, M. I.; FERREIRA, M. A.; VALADARES FILHO, S. C.; VALADARES, R. F. D.; QUEIROZ, A. C. Balanço de compostos nitrogenados e produção de proteína microbiana em novilhas leiteiras alimentadas com palma forrageira, bagaço de canade-açúcar e ureia associados a diferentes suplementos. Revista Brasileira de Zootecnia, Viçosa, v. 38, n. 5, p. 941-947, 2009.

RIBEIRO JÚNIOR, J. I. Análises estatísticas no SAEG: sistema para análises estatísticas. Viçosa, MG: UFV, 2001. $301 \mathrm{p}$.

RIBEIRO, A. C.; GUIMARÃES, P. T. G.; ALVAREZ, V. V. H. (Ed.). Recomendações para uso de corretivos e fertilizantes em Minas Gerais. $5^{\text {a }}$ aproximação. Viçosa, MG: CFSEMG/UFV, 1999. 359 p.

SANTOS, M. E. R.; FONSECA, D. M.; BALBINO, E. M.; MONNERAT, J. P. I. S.; SILVA, S. P. Capimbraquiária diferido e adubado com nitrogênio: produção e características da forragem. Revista Brasileira de Zootecnia, Viçosa, v. 38, n. 4, p. 650-656, 2009a. 
SANTOS, M. E. R.; FONSECA, D. M.; EUCLIDES, V. P. B.; NASCIMENTO JÚNIOR, D.; QUEIROZ, A. C.; RIBEIRO JÚNIOR, J. I. Características estruturais e índice de tombamento de Brachiaria decumbens cv. Basilisk em pastagens diferidas. Revista Brasileira de Zootecnia, Viçosa, v. 38, n. 4, p. 626-634, 2009b.

SILVA, D. J.; QUEIROZ, A. C. Análise de alimentos: métodos químicos e biológicos. 3. ed. Viçosa, MG: UFV, 2002. $165 \mathrm{p}$.

SILVA, J. F. C.; LEÃO, M. I. Fundamentos de nutrição dos ruminantes. Piracicaba: Livroceres, 1979. 380 p.

SILVA, R. R.; PRADO, I. N.; SILVA, F. F.; ALMEIDA, V. V. S.; SANTANA JÚNIOR, H. A.; QUEIROZ, A. C.; CARVALHO, G. G. P.; BARROSO, D. S. Comportamento ingestivo diurno de novilhos Nelore recebendo níveis crescentes de suplementação em pastejo de capimbraquiária. Revista Brasileira de Zootecnia, Viçosa, v. 39, n. 9, p. 2073-2080, 2010.

SILVA, R. R.; SILVA, F. F.; PRADO, I. N.; CARVALHO, G. G. P.; FRANCO, I. L.; ALMEIDA, V. S.; CARDOSO, C. P.; RIBEIRO, M. H. S. Comportamento ingestivo de bovinos. Aspectos metodológicos. Archivos de Zootecnia, Córdoba, v. 55, n. 211, p. 293-296, 2006.

SOLLENBERGER, L. E.; BURNS, J. C. Canopy characteristics, ingestive behaviour and herbage intake in cultivated tropical grasslands. In: INTERNATIONAL GRASSLAND CONGRESS, 19., 2001, São Pedro. Proceedings... São Pedro: [s.n], 2001. p. 321-327.

VALADARES, R. F. D.; BRODERICK, G. A.; VALADARES FILHO, C. M. K. Effect of replacing alfalfa with high moisture corn on ruminal protein synthesis estimated from excretion of total purine derivatives. Journal of Dairy Science, Champaing, v. 8, n. 12, p. 2686-2696, 1999.
VALADARES, R.F.D.; GONÇALVES, L.C.; SAMPAIO, I. B. M.; RODRIGUEZ, N. M.; VALADARES FILHO, S. C. Níveis de proteínas em deitas de bovinos. 3. pH, amônia e eficiência microbiana. Revista Brasileira de Zootecnia, Viçosa, v. 26, n. 6, p. 1264-1269, 1997a.

VALADARES, R. F. D.; VALADARES FILHO, S. C.; GONÇALVES, L. C.; RODRIGUEZ, N. M.; VALADARES FILHO, S. C.; SAMPAIO, I. B. Níveis de proteína em dietas de bovinos. 4. Concentrações de amônia ruminal e uréia plasmática e excreções de uréia e creatinina. Revista Brasileira de Zootecnia, Viçosa, v. 26, n. 6 , p. 1270-1278, $1997 \mathrm{~b}$.

VAN SOEST, P. J. Nutritional ecology of the ruminant. $2^{\text {th }}$ ed. Ithaca: Cornell University, 1994. $476 \mathrm{p}$.

VITOR, C. M. T.; FONSECA, D. M.; CÓSER, A. C.; MARTINS, C. E.; NASCIMENTO JÚNIOR, D.; RIBEIRO JÚNIOR, J. I. Produção de matéria seca e valor nutritivo de pastagem de capim-elefante sob irrigação e adubação nitrogenada. Revista Brasileira de Zootecnia, Viçosa, v. 38, n. 3, p. 435-442, 2009.

WILKERSON, V.A.; KLOPFENSTEIN, T. J.;BRITTON, R. A.; STOCK, R. A.; MILLER P. S. Metabolizable protein and amino acid requirements of growing beef cattle. Journal of Animal Science, Champaing, v. 71, n. 10, p. 2777-2784, 1993.

ZANINE, A. M.; SANTOS, E. M.; PARENTE, H. N.; FERREIRA, D. J.; CECON, P. R. Comportamento ingestivo de bezerros em pastos de Brachiaria brizantha e Brachiaria decumbens. Ciência Rural, Santa Maria, v. 36, n. 5, p. 825-832, 2006.

ZANINE, A. M.; SANTOS, E. M.; PARENTE, H. N.; FERREIRA, D. J.; OLIVEIRA, J. S.; LANA, E. P. Hábito de pastejo de novilhas em pastagens do gênero Brachiaria. Acta Scientiarum. Animal Sciences, Maringá, v. 29, n. 4, p. 365-369, 2007. 
